\title{
Larval Bradysia impatiens (Diptera: Sciaridae) Potential for Vectoring Pythium Root Rot Pathogens
}

\author{
S. E. Braun, J. P. Sanderson, and S. P. Wraight
}

First and second authors: Department of Entomology, Cornell University, Ithaca, NY 14853-0901; and third author: United States Department of Agriculture-Agricultural Research Service, Robert W. Holley Center for Agriculture \& Health, Ithaca, NY 14853-2901. Current address of first author: Department of Biology, Quinnipiac University, Hamden, CT 06518-1908. Accepted for publication 9 November 2011.

\begin{abstract}
Braun, S. E., Sanderson, J. P., and Wraight, S. P. 2012. Larval Bradysia impatiens (Diptera: Sciaridae) potential for vectoring Pythium root rot pathogens. Phytopathology 102:283-289.

A series of laboratory experiments were conducted to investigate the capacity of Bradysia impatiens (Johannsen) larvae to ingest propagules from two strains each of Pythium aphanidermatum (Edson) Fitzp. and $P$. ultimum Trow and transmit the pathogens to healthy geranium seedlings on a filter-paper substrate in petri dishes. The capacity of fungus gnat larvae to transmit $P$. aphanidermatum to seedlings rooted in a commercial peat-based potting mix and germination of Pythium oospores and hyphal swellings before and after passage through the guts of larval fungus gnats were also examined. Assays revealed that Pythium spp. transmission by

larval fungus gnats varied greatly with the assay substrate and also with the number and nature of ingested propagules. Transmission was highest $(65 \%)$ in the petri dish assays testing larvae fed P. aphanidermatum K-13, a strain that produced abundant oospores. Transmission of strain K-13 was much lower $(<6 \%)$ in plug cells with potting mix. Larvae were less efficient at vectoring $P$. ultimum strain PSN-1, which produced few oospores, and no transmission was observed with two non-oospore-producing strains: P. aphanidermatum Pa58 and P. ultimum P4. Passage of $P$. aphanidermatum K-13 through larval guts significantly increased oospore germination. However, decreased germination of hyphal swellings was observed following larval gut passage for strains of $P$. ultimum. These results expand previous studies suggesting that larval fungus gnats may vector Pythium spp.
\end{abstract}

Root-feeding insects influence crop production in a variety of settings, including agricultural fields, turf grass plots, and greenhouses $(5,7,15,24)$. In greenhouse crop-production systems, fungus gnats of the genus Bradysia (Diptera: Sciaridae) are ubiquitous pests. Larvae of these insects inhabit the soil or soilless potting media, where they feed primarily on decaying plant material and associated fungi (23), but larvae of several species, including the subject of the present study Bradysia impatiens (Johannsen), also consume root, stem, and occasionally leaf tissues of healthy plants, potentially causing significant damage, especially to seedlings and cuttings (38). Wounding by larvae may also have a variety of effects on plant susceptibility to disease. Some studies have shown that fungus gnat feeding damage can promote plant infection by pathogenic fungi $(13,25)$, whereas others have demonstrated no enhanced infection (12) or even potentially beneficial relationships, in which feeding damage can lead to induced resistance to plant pathogens (4). Fungus gnats also commonly coexist with diseased plants and may interact with plant pathogens as disease vectors $(14,15)$.

The external body surfaces of adult fungus gnats are readily contaminated with the aerial conidia of various plant-pathogenic fungi, including those of Fusarium, Thielaviopsis, and Verticillium spp., and these propagules can be transmitted to healthy plants $(3,8-10,12,14,22)$. However, fungus gnat adults are less likely to mechanically vector other important plant pathogens such as Pythium spp. in the class Oomycetes because these pathogens do not generate large numbers of aerially transmissible spores $(3,19)$. Oomycetes are normally dispersed via active movement of

Corresponding author: S. E. Braun; E-mail address: sarah.brown@ quinnipiac.edu

http://dx.doi.org/10.1094/PHYTO-09-11-0262

(C) 2012 The American Phytopathological Society asexual zoospores or passive transport in water, soil, or plant materials. Their persistence in the soil is marked primarily by the production of thick-walled sexual spores known as oospores in or on infected host tissues (37).

There are few published accounts of feeding by adult fungus gnats in the family Sciaridae and the reports are contradictory. Mercier (29) and Hungerford (16) reported feeding on nectar and a sodium arsenate-molasses solution, respectively, and Steffan (35) described them as feeding "primarily on organic ooze." However, Kennedy (23) described them as being aphagous, and attempts by Jarvis et al. (19) to induce B. impatiens adults to ingest Pythium oospores suspended in water with or without $1 \%$ glucose were unsuccessful. Thus, Bradysia adults are unlikely to carry pathogens in their digestive tracts and transmit them via defecation or regurgitation (nor would they be released from the decomposing bodies of dead adult gnats). It has also been demonstrated that Pythium propagules readily ingested by $B$. impatiens larvae are not transstadially transmitted to the adult gnats (3).

Though not passed to the adult stage, Pythium oospores and chlamydospore-like hyphal swellings have been shown to survive passage through the larval digestive tract and, upon excretion, infect plants grown in rockwool or petri dishes under laboratory conditions $(11,18,19)$. To our knowledge, however, no studies have examined the vectoring potential of larval fungus gnats in a potting mix system or the influence of pathogen strain on transmission. The primary objective of the current study was to evaluate the capacity of $B$. impatiens (Johannsen) larvae to ingest propagules from two strains each of Pythium aphanidermatum (Edson) Fitzp. and P. ultimum Trow and transmit the pathogens to healthy geranium seedlings under various conditions. Pythium propagules were characterized and enumerated to examine the basis for variability in vectoring potential of larval fungus gnats among different Pythium spp. and strains. Survival of oospores 
and hyphal swellings passed through the guts of larval fungus gnats was also quantified.

\section{MATERIALS AND METHODS}

Insect rearing. A laboratory colony of $B$. impatiens was established with adults collected from a greenhouse on the Cornell University campus. Adults and larvae were routinely reared in plastic containers $(9.8 \mathrm{~cm}$ in diameter by $6.2 \mathrm{~cm}$ in depth; Pioneer Plastics, Dixon, KY) with lids bearing holes $(5.5 \mathrm{~cm}$ in diameter) covered with nylon mesh $(95 \mu \mathrm{m})$ for ventilation. Each container was provided with $40 \mathrm{~g}$ of growing medium (Premier Pro-Mix BX, Quakertown, PA) mixed with $10 \mathrm{~g}$ (dry weight) of ground pinto beans (Goya Foods, Inc., Secaucus, NJ). The mix was then saturated with tap water, and 50 fungus gnat adults (predominately females) were introduced for egg production. Colony containers were maintained at $27 \pm 1{ }^{\circ} \mathrm{C}$ with $14 \mathrm{~h}$ of light and $10 \mathrm{~h}$ of darkness. In the following description of methods, these specific temperature and light conditions will be referred to as the "standard incubation conditions" or simply "standard conditions." New containers were established daily to provide a constant supply of all life stages. To obtain an even-aged cohort of fourthinstar fungus gnat larvae for use in bioassays, $\approx 200$ adult fungus gnats were collected from colony containers and released into a 45-by-45-by-45.5-cm cage in the laboratory at ambient temperature and allowed to oviposit on 90 -mm-diameter petri dishes (Becton Dickinson Labware, Franklin Lakes, NJ) that contained saturated cotton covered with a piece of black filter paper spread with a thin layer $(\approx 1.6 \mathrm{~g})$ of ground pinto beans (Phaseolus vulgaris L.). After $24 \mathrm{~h}$, petri dishes were removed from the cages and the fungus gnat cultures maintained until the larvae completed development to the fourth instar. Additional water and pinto beans were added to the dishes as needed. Fourth-instar larvae were readily identified on the surface of the filter paper and transferred to bioassay containers using a fine brush.

Plant propagation. Geranium seed (Pelargonium $\times$ hortorum L.H. Bailey 'Orbit White', Goldsmith Seeds) were surface sterilized in a $0.5 \%$ sodium hypochlorite solution and germinated individually on top of a filter paper disk (42.5 $\mathrm{mm}$ in diameter) saturated with $400 \mu \mathrm{l}$ of sterile distilled water $\left(\mathrm{SDH}_{2} \mathrm{O}\right)$ in 47-mm-diameter friction-lid petri dishes (catalog number 09-720501; Fisher Scientific, Pittsburgh, PA). The seeds were incubated in darkness for 3 days at room temperature. Seedlings were maintained under standard conditions and watered daily with $200 \mu \mathrm{l}$ of $\mathrm{SDH}_{2} \mathrm{O}$ until used in bioassays. The seedlings were oriented, for the most part, horizontally in the petri dishes (lying on the filter paper).

Seeds used in plug cell bioassays were planted in tap-watersaturated peat-based Redi-earth Plug and Seedling Mix (Sun Gro Horticulture Canada Ltd., Vancouver, BC, Canada) within individual plug cells $(\approx 14 \mathrm{ml}$ volume) cut from 128 -well plastic plug trays (Dillen Products/Myers Industries Inc., Middlefield, OH) and incubated in darkness at $23^{\circ} \mathrm{C}$ until germination (4 days). Seedlings were maintained under standard conditions until used in bioassays.

Pathogen maintenance. Pythium aphanidermatum strain Pa58 and $P$. ultimum strain $\mathrm{P} 4$ were obtained from a culture collection maintained at Cornell University, Ithaca, NY (E. B. Nelson lab), and $P$. aphanidermatum strain K-13 and $P$. ultimum strain PSN-1 were obtained from a collection maintained at the Long Island Horticultural Research and Extension Center, Riverhead, NY (M. L. Daughtrey lab). P. aphanidermatum cultures were grown in 60-mm-diameter petri dishes on V8 juice agar (composed of 100 $\mathrm{ml}$ of $\mathrm{V} 8$ juice, $400 \mathrm{ml}$ of $\mathrm{H}_{2} \mathrm{O}, 1.5 \mathrm{~g}$ of $\mathrm{CaCO}_{3}$, and $10 \mathrm{~g}$ of Bacto Agar) and maintained in the dark at $27 \pm 1^{\circ} \mathrm{C}$. P. ultimum cultures were grown on half-strength corn meal agar (composed of $8.5 \mathrm{~g}$ of corn meal agar per liter of $\mathrm{SDH}_{2} \mathrm{O}$ ) and maintained in the dark at $25 \pm 1^{\circ} \mathrm{C}$. One-week-old $P$. aphanidermatum and 10-day-old $P$. ultimum cultures were used in all experiments and for inoculating plants for periodic reisolation of the pathogens. Every 2 weeks, the pathogens were reisolated from 11-day-old geranium seedlings that had been inoculated 3 days earlier by placing a 6-mmdiameter Pythium-colonized agar disk on the root tip. Each infected seedling was placed in a 90 -mm-diameter petri dish and covered with $2 \%$ molten water agar supplemented with the antibiotics rifampicin, penicillin $\mathrm{G}$, and kanamycin (1.0, 1.0, and $2.5 \mathrm{ml} /$ liter of $\mathrm{SDH}_{2} \mathrm{O}$, respectively, and each at $0.01 \mathrm{~g} / \mathrm{ml}$ ) (WARP). Pythium hyphae that grew rapidly through the agar were excised from the surface of the medium and transferred to a fresh WARP plate.

Transmission study with seedlings grown in plastic dishes. Three laboratory bioassays (16 to 20 replicates per treatment) were conducted to determine whether $P$. aphanidermatum consumed by fungus gnat larvae could be transmitted to geranium seedlings in petri dishes. Using a fine brush, individual earlyfourth-instar larvae were transferred from rearing dishes to each of 16 to 20 petri dishes containing $2 \%$ water agar. Larvae were maintained in the dark at $27 \pm 1^{\circ} \mathrm{C}$ and allowed to feed on the water agar for $6 \mathrm{~h}$ to clear their guts. Larvae were then transferred to V8 agar plates (one larva per plate) containing a $P$. aphanidermatum culture of either strain K-13 or Pa58 from which the aerial mycelium had been removed using a sterile scalpel. After $15 \mathrm{~h}$ of feeding, larvae were removed from the culture plates and transferred individually onto sterile filter paper saturated with $\mathrm{SDH}_{2} \mathrm{O}$ and allowed to move on this substrate for $10 \mathrm{~min}$ to dislodge surface contaminants. At this point, each larva was placed in a tight-lid petri dish (47 $\mathrm{mm}$ in diameter) lined with a piece of saturated filter paper (with $400 \mu \mathrm{l}$ of $\mathrm{SDH}_{2} \mathrm{O}$ ) next to one 7-dayold geranium seedling. One larva was used in each bioassay dish because preliminary experiments revealed that feeding damage inflicted by more than one larva caused significant plant mortality. Two control treatments included individual seedlings with no fungus gnat larvae added and seedlings with one larva treated as described above but not fed on Pythium. Seedlings were maintained under standard conditions and watered daily with $200 \mu \mathrm{l}$ of $\mathrm{SDH}_{2} \mathrm{O}$. Mortality was recorded after 7 days. P. aphanidermatum was reisolated from infected seedlings at the end of the experiment.

Two assays (20 replicates per treatment) of the aforementioned experiment were conducted with half-strength corn meal agar culture plates of $P$. ultimum strains P4 and PSN-1. Seedlings were maintained at $25 \pm 1{ }^{\circ} \mathrm{C}$ with $14 \mathrm{~h}$ of light and $10 \mathrm{~h}$ of darkness and watered daily. Mortality was recorded after 10 days. P. ultimum was reisolated from infected seedlings at the end of the experiment as described above.

Transmission study with seedlings grown in plug mix. Three laboratory bioassays (13 to 23 replicates per treatment) were conducted to determine whether $P$. aphanidermatum strain K-13 consumed by fungus gnat larvae could be transmitted to cause infection in geranium seedlings rooted in plug mix (see plantpropagation section). Fourth-instar larvae were first fed on $P$. aphanidermatum culture plates as described above (two larvae per dish in this experiment) and then placed on the surface of tapwater-saturated plug mix adjacent to a geranium seedling (two larvae per cell). Plug cells were watered every other day with $1 \mathrm{ml}$ of tap water and maintained under standard incubation conditions. Control treatments were the same as those in the petri dish experiment. Individual plug cells were nested randomly and isolated from one another within an intact, well-drained plug tray. Mortality was recorded after 7 days. $P$. aphanidermatum was reisolated from infected seedlings at the end of the experiment as described above.

Concentration and characterization of Pythium spp. oospores and/or hyphal swellings. The concentration of oospores or hyphal swellings was estimated in 12 replicate culture plates of each Pythium sp. and strain (7-day-old plates of P. aphanider- 
matum strains Pa58 and K-13 and 10-day-old plates of P. ultimum strains P4 and PSN-1). Aerial mycelium was removed from each plate using a sterile scalpel, and the number of total oospores and/or hyphal swellings in focus (within a $0.126 \mathrm{~mm}^{2}$ area) at the agar surface was counted using $\times 200$ magnification. Counts were made only at the agar surface, because preliminary observations revealed that very few spores were formed below this level. Small samples of mature oospores or hyphal swellings produced by the various Pythium strains were characterized with respect to approximate size and wall thickness for the purpose of making gross morphological comparisons; 10 oospores and/or 10 hyphal swellings produced by each Pythium strain were measured from micrographs of the propagules taken at $\times 400$ magnification. Strain PSN-1 was unique among the four strains in producing both oospores and hyphal swellings, and the relative numbers of these propagules were determined by examination of four replicate 10-day-old culture plates.

Pythium spp. oospore and hyphal swelling germination counts. Three laboratory bioassays ( 8 to 10 replicates per treatment) were conducted to examine the germination rate of $P$. aphanidermatum oospores before and after passage through larval fungus gnats. Germination of oospores before larval passage was determined by using a sterile scalpel to remove 3-by-3-by-1-mm pieces of agar from $P$. aphanidermatum cultures of strains K-13 and Pa58. Individual pieces of agar from each plate were placed into separate sterile $1.5-\mathrm{ml}$ microcentrifuge tubes with $150 \mu \mathrm{l}$ of $\mathrm{SDH}_{2} \mathrm{O}$ and ground for $30 \mathrm{~s}$ with a sterile $1.5-\mathrm{ml}$ Kontes pellet pestle (Kimble Chase, Vineland, NJ) to dislodge oospores from the agar matrix. The microcentrifuge tubes were then vortexed continuously for $30 \mathrm{~s}$ at fast speed (Scientific Products Deluxe Mixer S8220, McGaw Park, IL) to further disperse the agar and homogenize the suspension. A 50- $\mu$ sample of the suspension from each tube was pipetted onto individual WARP or nutrientrich potato dextrose agar (PDA) plates (composed of $6 \mathrm{~g}$ of PD powder [MP Biomedicals, Solon, $\mathrm{OH}$ ] and $5 \mathrm{~g}$ of Bacto Agar supplemented with WARP antibiotics in $250 \mathrm{ml}$ of $\mathrm{SDH}_{2} \mathrm{O}$ ) and spread with a sterile glass rod. The proportion of germinating oospores in a $0.875-\mathrm{mm}^{2}$ area in the center of each plate was enumerated at $\times 400$ magnification after $24 \mathrm{~h}$ of incubation in the dark at $27 \pm 1^{\circ} \mathrm{C}$.

Oospore germination following larval digestion was examined by placing individual fourth-instar larvae on water agar plates for $6 \mathrm{~h}$ to clear their guts and then transferring them to V8 agar plates containing a $P$. aphanidermatum culture of either strain K-13 or $\mathrm{Pa} 58$ as described for previous experiments. After $15 \mathrm{~h}$, larvae were removed from the culture plates and transferred onto $\mathrm{SDH}_{2} \mathrm{O}$ saturated sterile filter paper to dislodge surface contaminants. Larvae were then placed individually in 60 - $\mathrm{mm}$-diameter petri dishes containing WARP agar or PDA to defecate. After $2 \mathrm{~h}$, larvae were removed from the plates, and the plates were incubated in the dark at $27 \pm 1^{\circ} \mathrm{C}$ for $24 \mathrm{~h}$. The proportion of germinating oospores in fecal deposits was determined in each plate at $\times 400$ magnification.

Additional laboratory bioassays (10 replicates per treatment) of the above-described experiment were conducted to examine the germination rates of $P$. ultimum strain $\mathrm{P} 4$ and PSN-1 oospores and/or hyphal swellings on WARP or PDA agar at $25 \pm 1{ }^{\circ} \mathrm{C}$ before and after passage through larval fungus gnats. Five $5-\mu l$ samples of the suspension from each P. ultimum control sample were pipetted onto individual WARP or PDA plates (without spreading the sample) for counting. Hyphal swelling germination counts were conducted after $3 \mathrm{~h}$ of plate incubation; oospore germination was recorded after $24 \mathrm{~h}$.

Statistical analyses. Statistical tests were conducted using the JMP software, version 7.0 (32). Analysis of variance (ANOVA) followed by the Student's $t$ tests for means comparisons were used to examine differences in the proportions of infected seedlings in petri dish experiments and to compare oospore or hyphal swelling germination rates and densities of spores in plates. All proportions were arcsine transformed. The $\log (x+1)$ transformation was applied to spore concentrations before ANOVA to normalize the distributions and equalize the treatment variances.

\section{RESULTS}

Transmission study with seedlings in plastic dishes and plug mix. In petri dishes, plant death due to larval fungus gnat transmission of Pythium was greatest $(65 \%)$ when the insects were fed on $P$. aphanidermatum strain $\mathrm{K}-13$ before their placement near seedlings. In plug cells, however, few seedlings died (6\%) when exposed to larvae that had fed on strain K-13 (Table 1). Larvae were less efficient at transmitting the other three strains; in the petri dish assays, $P$. aphanidermatum strain Pa58 and P. ultimum strain P4 were not transmitted (no plant mortality) and P. ultimum strain PSN-1 killed only $8 \%$ of the seedlings. No seedlings died in the seedling-only controls, and few seedlings died due to fungus gnat feeding alone ( $<2 \%$ only in petri dish assays) (Table $1 ;$ Fig. 1$)$.

Characterization of Pythium spp. oospores and/or hyphal swellings in culture plates. The mature propagules produced by the various Pythium strains were similar in shape and size; all were essentially spherical, with mean diameters of $\approx 20$ to $23 \mu \mathrm{m}$. Strain K-13 of $P$. aphanidermatum produced large numbers of oospores (Table 2). These propagules were $21.6 \pm 0.4 \mu \mathrm{m}$ in diameter with distinct cell walls $1.7 \pm 0.05 \mu \mathrm{m}$ thick. $P$. aphanidermatum strain $\mathrm{Pa}-58$ produced significantly fewer oospores than strain $\mathrm{K}-13\left(F_{[1,22]}=15.4, P=0.0007\right)($ Table 2$)$

TABLE 1. Larval fungus gnat-mediated transmission of Pythium spp. in laboratory assays with geranium seedlings

\begin{tabular}{|c|c|c|c|}
\hline Treatment & Number of assays & Number of plants & Mean plant mortality $(\%) \pm \mathrm{SE}$ (range over assays) ${ }^{2}$ \\
\hline \multicolumn{4}{|l|}{ Petri dishes } \\
\hline \multicolumn{4}{|l|}{ Pythium aphanidermatum } \\
\hline Control & 3 & 56 & 0 \\
\hline Fungus gnats $+P$. aphanidermatum $\mathrm{Pa} 58$ & 3 & 56 & 0 \\
\hline Fungus gnats $+P$. aphanidermatum $\mathrm{K}-13$ & 3 & 56 & $65.42 \pm 7.37 \mathrm{~b}(56.25-80)$ \\
\hline \multicolumn{4}{|l|}{ P. ultimum } \\
\hline Control & 2 & 40 & 0 \\
\hline Fungus gnats $+P$. ultimum PSN-1 & 2 & 40 & $7.5 \pm 3.54(5-10)$ \\
\hline \multicolumn{4}{|l|}{ Plug cells } \\
\hline \multicolumn{4}{|l|}{ P. aphanidermatum } \\
\hline Control & 3 & 40 & 0 \\
\hline Fungus gnats & 3 & 50 & 0 \\
\hline Fungus gnats $+P$. aphanidermatum $\mathrm{K}-13$ & 3 & 50 & $5.68 \pm 2.84(0-8.70)$ \\
\hline
\end{tabular}

${ }^{\mathrm{z}}$ Percentages $( \pm$ standard errors $[\mathrm{SE}])$ followed by same letter are not significantly different $\left(F_{[1,4]}=62.4, P=0.0014\right)$. 
and, in all of our cultures of this strain, the oospores observed to be developing within the oogonia rarely reached maturity (rarely developed thick walls) (Fig. 1). No hyphal swelling were observed in cultures of either of the $P$. aphanidermatum strains.

There was no significant difference in the mean number of total propagules (oospores and/or hyphal swellings) produced by $P$. ultimum strains P4 and PSN-1 $\left(F_{[1,22]}=0.20, P=0.66\right)$. $P$. ultimum strain PSN-1 produced both mature oospores and hyphal swellings, whereas strain P4 produced hyphal swellings only (Table 2). In the 10-day-old culture plates, hyphal swellings were present in substantially greater numbers than oospores; on average, $80.7 \pm 1.6 \%$ of the total propagules in each plate were hyphal swellings. The oospores measured $20.5 \pm 0.9 \mu \mathrm{m}$ in diameter with a wall thickness of $1.5 \pm 0.1 \mu \mathrm{m}$, whereas the hyphal swellings were $23.3 \pm 1 \mu \mathrm{m}$ in diameter with a wall thickness of $1.3 \pm$ $0.1 \mu \mathrm{m}$. P. ultimum strain P4 hyphal swellings were similar in size $(22.8 \pm 0.7 \mu \mathrm{m})$ and wall thickness $(1.4 \pm 0.1 \mu \mathrm{m})$ to those produced by strain PSN-1 (Table 2; Fig. 1).

Sizes of the oospores and hyphal swelling reported above for $P$. aphanidermatum and $P$. ultimum were similar to those reported by Van der Plaats-Niterink (37) and Matthews (28).

Pythium spp. oospore and hyphal swelling germination counts. Nearly three times more oospores of $P$. aphanidermatum strain K-13 germinated after passage through larval fungus gnats (19\%) than without larval gut passage (7\%). There was no effect of growth medium (PDA versus WARP) on germination and no medium-gut passage interaction (Table 3). No oospores of $P$. aphanidermatum strain Pa58 germinated with or without passage

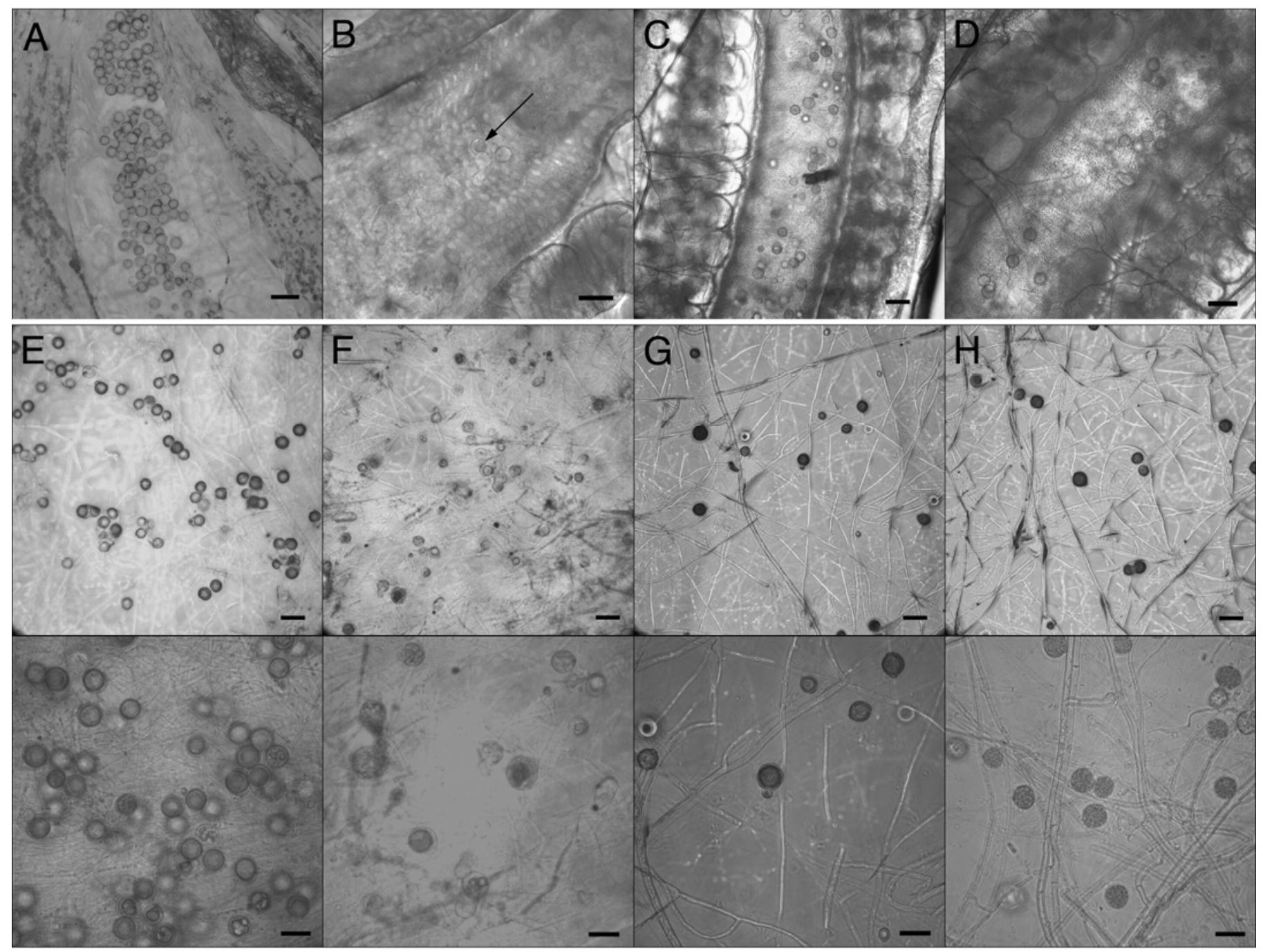

Fig. 1. A to D, Oospores of Pythium aphanidermatum strain K-13 and $P$. aphanidermatum strain Pa58, oospores and hyphal swellings of $P$. ultimum strain PSN-1, and hyphal swellings of $P$. ultimum strain P4, respectively, in the digestive tracts of fungus gnat larvae. Arrow indicates oospore. E to H, Surface of $P$. aphanidermatum strain K-13, P. aphanidermatum strain Pa58, P. ultimum strain PSN-1, and P. ultimum strain P4 culture plates, respectively, where fungus gnat larvae were placed to feed; upper image scale bars $=50 \mu \mathrm{m}$, lower image scale bars $=30 \mu \mathrm{m}$.

TABLE 2. Mean numbers of oospores or hyphal swellings in Pythium culture plates

\begin{tabular}{|c|c|c|c|}
\hline Treatment & Propagule type & Number of plates & Mean number of propagules $/ \mathrm{mm}^{2} \pm \mathrm{SE}(\text { range })^{\mathrm{z}}$ \\
\hline \multicolumn{4}{|c|}{ Pythium aphanidermatum } \\
\hline Strain Pa58 & Oospores & 12 & $130.3 \pm 19.3$ a $(40-302)$ \\
\hline Strain K-13 & Oospores & 12 & $240.1 \pm 22.8$ b (135-405) \\
\hline Strain P4 & Hyphal swellings & 12 & $52.9 \pm 6.6$ a (16-87) \\
\hline Strain PSN-1 & Oospores + hyphal swellings & 12 & $47.6 \pm 5.7$ a (16-79) \\
\hline
\end{tabular}

${ }^{\mathrm{z}}$ Percentages $( \pm$ standard error $[\mathrm{SE}])$ followed by same letter within a species are not significantly different $\left(P\right.$. aphanidermatum: $F_{[1,22]}=15.4, P=0.0007 ; P$. ultimum: $\left.F_{[1,22]}=0.20, P=0.66\right)$. 
through larval fungus gnats (Table 3 ). Few oospores of $P$. ultimum strain PSN-1 germinated after larval gut passage $(4 \%)$ but there was no germination of spores without larval passage.

Significantly fewer hyphal swellings of $P$. ultimum strains PSN1 and P4 germinated after passage through larval fungus gnats. Gut passage reduced viability of strain PSN-1 from 88 to $37 \%$ and viability of strain P4 from 90 to $4 \%$ (Table 3). As observed with oospores, there were no significant main effects of medium on hyphal swelling germination. With strain P4, there was a weakly significant interaction $(P=0.02)$ between growth medium and gut passage, with a greater reduction in viability observed on WARP agar; however, the main effect of greatly reduced viability after gut passage was evident regardless of the medium used.

\section{DISCUSSION}

Relatively few studies have examined the importance of larval fungus gnats in the transmission of plant pathogens $(8,11,14$, $18,19)$, and ours is the first to consider the importance of plant growing medium. We observed high levels of transmission $(65 \%$ seedling mortality) in our petri dish assays with $P$. aphanidermatum strain K-13 but very low levels ( $<6 \%$ mortality) in the plug-cell assays with a peat-based potting medium. The very different physicochemical properties of the filter paper versus potting medium substrates may be largely responsible for the these results but it is also possible that the microbial composition of the nonsterilized plug mix influenced the level of observed Pythium infection. Pythium suppressive characteristics have been reported for some peat-based potting mixes $(17,36)$. Regardless of the inhibition mechanism or mechanisms, these findings suggest that the Pythium-vectoring potential of larval fungus gnats may be much lower under commercial growing conditions than results from recent laboratory studies suggest.

Our study also indicates that the capacity to be vectored by larval fungus gnats varies greatly among Pythium spp. and strains and provides evidence that this variability derives, in large part, from differences in the number and nature of the propagules produced by each pathogen. Transmission rate was high with $P$. aphanidermatum strain K-13, which produced the greatest number of oospores per plate, and low with $P$. ultimum strain PSN-1, which produced substantially fewer oospores. Additionally, transmission occurred only with those Pythium strains that produced numerous mature (thick-walled) oospores. $P$. aphanidermatum strain Pa58, a strain that produced many oogonia and immature oospores but few mature oospores, was not transmitted (abortive oospore development is a common phenomenon among Pythium isolates) (37). Finally, assays revealed low transmission of oospore-producing strain PSN-1 of P. ultimum but no transmission of $P$. ultimum $\mathrm{P} 4$, a strain that produced abundant hyphal swellings but no oospores.

Our finding of no transmission of strain P4 is in sharp contrast to the observations of Hyder et al. (18), who reported high rates of

TABLE 3. Mean percentage of germinating Pythium aphanidermatum oospores and P. ultimum oospores or hyphal swellings with or without passage through larval fungus gnat guts

\begin{tabular}{|c|c|c|c|c|}
\hline Treatment $^{\mathrm{x}}$ & Number of replicates & Total propagules & Germination $(\%)^{\mathrm{y}}$ & ANOVA $^{\mathrm{z}}$ \\
\hline \multicolumn{5}{|l|}{ Pythium aphanidermatum } \\
\hline \multicolumn{5}{|l|}{ Strain Pa58 oospores } \\
\hline Control on PDA & 8 & 21 & 0 & \\
\hline Mean germination without gut passage & $\ldots$ & $\ldots$ & 0 & \\
\hline Fungus gnat larvae on PDA & 8 & 6 & 0 & \\
\hline Fungus gnat larvae on WARP & 28 & 20 & 0 & \\
\hline Mean germination after gut passage & $\cdots$ & $\ldots$ & 0 & \\
\hline Control on PDA & 8 & 29 & $6.9 \pm 4.2$ & \multirow{6}{*}{$\begin{array}{l}\mathrm{M}: F_{[1,58]}=0.0007, P=0.98 \\
\mathrm{GP}: F_{[1,58]}=15.00 ; P=0.0003 \\
\mathrm{M} \times \mathrm{GP}: F_{[1,58]}=0.16 ; P=0.69\end{array}$} \\
\hline Control on WARP & 28 & 196 & $7.1 \pm 1.9$ & \\
\hline Mean germination without gut passage & $\ldots$ & $\ldots$ & $7.1 \pm 1.7 \mathrm{a}$ & \\
\hline Fungus gnat larvae on PDA & 8 & 123 & $19.5 \pm 3.3$ & \\
\hline Fungus gnat larvae on WARP & 28 & 459 & $18.3 \pm 2.1$ & \\
\hline Mean germination after gut passage & $\ldots$ & $\ldots$ & $18.6 \pm 1.8 \mathrm{~b}$ & \\
\hline \multicolumn{5}{|l|}{ P. ultimum } \\
\hline Fungus gnat larvae on WARP & 20 & 57 & $3.5 \pm 1.5$ & \\
\hline Mean germination after gut passage & $\ldots$ & $\ldots$ & $4.4 \pm 1.6$ & \\
\hline \multicolumn{5}{|l|}{ Strain PSN-1 hyphal swellings } \\
\hline Control on PDA & 10 & 41 & $85.4 \pm 4.9$ & \multirow{6}{*}{$\begin{array}{l}\mathrm{M}: F_{[1,30]}=0.44, P=0.51 \\
\mathrm{GP}: F_{[1,30]}=44.08, P<0.0001 \\
\mathrm{M} \times \mathrm{GP}: F_{[1,30]}=2.85, P=0.10\end{array}$} \\
\hline Control on WARP & 10 & 54 & $90.7 \pm 5.4$ & \\
\hline Mean germination without gut passage & $\ldots$ & $\ldots$ & $88.4 \pm 3.6 \mathrm{a}$ & \\
\hline Fungus gnat larvae on PDA & 10 & 52 & $48.1 \pm 8.3$ & \\
\hline Fungus gnat larvae on WARP & 10 & 70 & $28.6 \pm 8.6$ & \\
\hline Mean germination after gut passage & $\cdots$ & $\ldots$ & $36.9 \pm 6.3 \mathrm{~b}$ & \\
\hline \multicolumn{5}{|l|}{ Strain P4 hyphal swellings } \\
\hline Control on PDA & 10 & 230 & $85.7 \pm 2.0$ & \multirow{3}{*}{$\begin{array}{l}\mathrm{M}: F_{[1,30]}=0.0032, P=0.95 \\
\mathrm{GP}: F_{[1,30]}=499.82, P<0.0001 \\
\mathrm{M} \times \mathrm{GP}: \mathrm{F}_{[1,30]}=6.33, P=0.02\end{array}$} \\
\hline Control on WARP & 10 & 355 & $92.4 \pm 1.4$ & \\
\hline Mean germination without gut passage & $\ldots$ & & $89.7 \pm 1.4 \mathrm{a}$ & \\
\hline
\end{tabular}

${ }^{x}$ PDA = potato dextrose agar and WARP = water agar supplemented with the antibiotics rifampicin, penicillin G, and kanamycin.

${ }^{\mathrm{y}}$ Percent germination ( \pm standard error) determined after incubation of oospores for $24 \mathrm{~h}$ and incubation of hyphal swellings for $3 \mathrm{~h}$ at $25^{\circ} \mathrm{C}$.

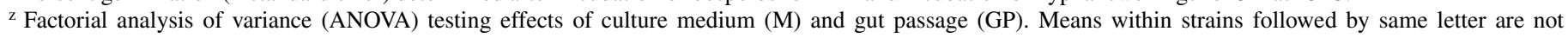
significantly different. 
infection (67\%) among pepper seedlings exposed to larvae fed on P. ultimum hyphal swellings. This disparity could be the result of numerous factors, including differences in virulence of the pathogen strains, susceptibility of the host plants, bioassay methods, and propagule concentrations. It is particularly noteworthy that the number of hyphal swellings in the larval gut illustrated in Hyder et al. (18) is much higher than any number we observed in our assays (Fig. 1). It is also possible, however, that the hyphal swellings produced by our strains of $P$. ultimum were less robust (less resistant to digestion) than those in the study by Hyder et al. (18).

Many Pythium spp. and strains produce hyphal swellings $(21,27,37)$. These asexual spore-like propagules closely resemble sporangia and were commonly identified as such in earlier studies $(1,6,33)$. The term sporangium is no longer applied to these structures, however, because they produce no spores (germination is exclusively by production of germ tubes). Production of hyphal swellings does not appear to be correlated with production of other propagules; some Pythium strains produce hyphal swellings in addition to sporangia and others produce only hyphal swellings; hyphal swelling may be the only spore-like propagules produced by Pythium strains that produce neither oospores nor sporangia $(26,37)$. Though not generally referred to as resistant spores, hyphal swellings of at least some Pythium spp. are capable of surviving many months in soil, making them functionally analogous to chlamydospores (33). In fact, chlamydospores (thick-walled asexual spores derived form hyphal cells) have been described from at least two Pythium spp. (P. dimorphum and P. tracheiphilum) (37), and it may be that the hyphal swellings of many other species are closer to chlamydospores than generally recognized. The spherical hyphal swellings in the larval gut micrograph shown by Hyder et al. (18), for example, possess prominent walls of remarkably uniform thickness and resemble the thick-walled chlamydospores of $P$. dimorphum illustrated in Van der Plaats-Niterink (37). Van der Plaats-Niterink (37) described the walls of the P. dimorphum chlamydospores as being "of uneven thickness, up to $2 \mu \mathrm{m}$." It would seem a reasonable hypothesis that variability in this trait is a factor in surviving passage through the fungus gnat gut. In our tests, gut passage reduced the viability of hyphal swellings of $P$. ultimum strains PSN-1 and P4 from 88 to $37 \%$ and 90 to $4 \%$, respectively (Table 3). Unfortunately, the report by Hyder et al. (18) does not include a description of the $P$. ultimum hyphal swellings or rates of germination for comparison.

With regard to germination potential of Pythium propagules, our findings of limited, slow germination of freshly harvested oospores (maximum 20\% germination within $24 \mathrm{~h}$ ) and extensive, rapid germination of hyphal swellings (maximum $92 \%$ germination within $3 \mathrm{~h}$ ) are in accord with previous studies $(33,34)$. Air drying or aging of oospores for 1 to 2 weeks in nonsterile soil extract has been shown to significantly increase rates of germination (to $\approx 90 \%$ ) for both $P$. aphanidermatum and $P$. ultimum $(2,20,31,33)$. The loss of endogenous carbon over longer time periods correlates negatively with the germinability and virulence of oospores (30). Perhaps the Pythium spp. oospores that did not germinate in our study were not mature or given sufficient time and appropriate drying conditions to break dormancy and achieve maximum germination potential. Other factors to consider in oospore germination include soil temperature, $\mathrm{pH}$, and moisture content, and the values of these parameters vary depending on Pythium spp. $(2,30)$.

Ours is not the first observation of a positive effect of invertebrate-gut passage on germinability of $P$. aphanidermatum oospores. Stanghellini and Russell (34) reported that passage of $P$. aphanidermatum oospores through live water snails increased germination to $94 \%$ and suggested that "enzymes present in the snail intestine increased oospore permeability which allowed the diffusion of nutrients required for subsequent germination." Such marked changes in germination following gut passage could obviously influence vectoring potential, and additional studies are needed to better understand biological factors mediating oospore and hyphal swelling germination and the numbers of these propagules necessary to cause plant infection.

Laboratory studies have now revealed that fungus gnat larvae can serve as vectors of certain Pythium spp. and strains under ideal conditions $(18,19)$ but the vectoring potential of these pests in the commercial greenhouse setting remains unexplored. These insects are slow-moving cryptic inhabitants of soil; therefore, it seems highly unlikely that they play any significant role in vectoring Pythium spp. between greenhouse facilities, between benches in a greenhouse, or between separated pots on a greenhouse bench. Transmission would be most likely within a single root system, among multiple plants within a single pot or hydroponic trough, or between cells of propagation trays or seedling flats. However, under these circumstances, Pythium spp. are fully capable of unassisted movement (via zoospores or hyphal growth). In addition, rates of transmission are almost certainly directly related to propagule concentration in the fungus gnat gut, and concentrations as high as those shown in Figure 1 of this study or Figure 4A of Hyder et al. (18) would probably be rare under natural conditions (we observed only sparse production of oospores and/or hyphal swellings in diseased roots of geranium seedlings).

The findings of this and previous studies on Bradysia-Pythium interactions $(3,18,19)$ as well as various characteristics of fungus gnat biology and behavior lead us to conclude that these insects are not important vectors of Pythium spp. Therefore, fungus gnat management should not be considered an essential part of the Pythium disease control equation (fungus gnats need not be intensively controlled out of fear of vectored Pythium diseases). This is not to suggest, however, a return to old views of fungus gnats as primarily nuisance pests, because the larvae can sever primary roots or tunnel into the stems of small plants or cuttings with lethal effects, and adults can mechanically transmit many virulent plant-pathogenic conidial fungi $(3,8-10,12,14,22)$. Overall, this study emphasizes the importance of examining the basic biology of fungus gnats and Pythium spp. to better understand the ways in which they interact.

\section{ACKNOWLEDGMENTS}

This research was funded, in part, through Specific Cooperative Agreements between the United States Department of AgricultureAgricultural Research Service (USDA-ARS) Plant Protection Research Unit and the Cornell University Department of Entomology, Ithaca, NY (Specific Cooperative Agreements 58-1907-5-555 and 58-1907-4-447) funded by the USDA-ARS, as part of the Floriculture and Nursery Research Initiative. Additional funding came from an NSF Graduate Research Fellowship and a Grace H. Griswold Endowment Grant to S. E. Braun. We thank E. B. Nelson and M. L. Daughtrey of Cornell University for providing strains of $P$. aphanidermatum and P. ultimum, and M. Ramos for technical support.

\section{LITERATURE CITED}

1. Alexopoulos, C. J., Mims, C. W., and Blackwell, M. 1996. Introductory Mycology, 4th ed. John Wiley \& Sons, New York.

2. Ayers, W. A., and Lumsden, R. D. 1975. Factors affecting production and germination of oospores of three Pythium species. Phytopathology 65:1094-1100.

3. Braun, S. E., Castrillo, L. A., Sanderson, J. P., Daughtrey, M. L., and Wraight, S. P. 2010. Transstadial transmission of Pythium in Bradysia impatiens and lack of adult vectoring capacity. Phytopathology 100:1307-1314.

4. Braun, S. E., Sanderson, J. P., Nelson, E. B., Daughtrey, M. L., and Wraight. S. P. 2009. Fungus gnat feeding and mechanical wounding inhibit Pythium aphanidermatum infection of geranium seedlings. Phytopathology 99:1421-1428.

5. Brown, M. V., Schmitt, J. J., Ranger, S., and Hogmire, H. W. 1995. Yield reduction in apple by edaphic woolly apple aphid (Homoptera: Aphididae) populations. J. Econ. Entomol. 88:127-133. 
6. Campbell, W. A., and Sleeth, B. 1946. Variability of Pythium ultimum from Guayule. Mycologia 38:24-39.

7. Crutchfield, B. A., and Potter, D. A. 1995. Damage relationships of Japanese beetle and southern masked chafer (Coleoptera: Scarabaeidae) grubs in cool-season turfgrasses. J. Econ. Entomol. 88:1049-1056.

8. El-Hamalawi, Z. A. 2008. Acquisition, retention and dispersal of soilborne plant pathogenic fungi by fungus gnats and moth flies. Ann. Appl. Biol. 153:195-203.

9. El-Hamalawi, Z. A., and Stanghellini, M. E. 2005. Disease development on Lisianthus following aerial transmission of Fusarium avenaceum by adult shore flies, fungus gnats, and moth flies. Plant Dis. 89:619-623.

10. Elmer, W. H. 2008. Preventing spread of Fusarium wilt of Hiemalis begonias in the greenhouse. Crop Prot. 27:1078-1083.

11. Gardiner, R. B., Jarvis, W. R., and Shipp, J. L. 1990. Ingestion of Pythium spp. by larvae of the fungus gnat Bradysia impatiens (Diptera: Sciaridae). Ann. Appl. Biol. 116:205-212.

12. Gillespie, D. R., and Menzies, J. G. 1993. Fungus gnats vector Fusarium oxysporum f. sp. radicis-lycopersici. Ann. Appl. Biol. 123:539-544.

13. Graham, C. L., and McNeill, M. J. 1972. Soybean crown and root damage by Bradysia coprophila. J. Econ. Entomol. 65:597-599.

14. Harris, M. A. 1995. Dissemination of the phytopathogen Thielaviopsis basicola by the fungus gnat Bradysia coprophila and biological control of these pests by Fusarium proliferatum and steinernematid nematodes. Doctoral dissertation, University of Georgia, Athens.

15. Harris, M. A., Gardner, W. A., and Oetting, R. D. 1996. A review of the scientific literature on fungus gnats (Diptera: Sciaridae) in the genus Bradysia. J. Entomol. Sci. 31:252-271.

16. Hungerford, H. B. 1916. Sciara maggots injurious to potted plants. J. Econ. Entomol. 9:538-549.

17. Hunter, P. J., Petch, G. M., Calvo-Bado, L. A., Pettitt, T. R., Parsons, N. R., Morgan, J. A. W., and Whipps, J. M. 2006. Differences in microbial activity and microbial populations of peat associated with suppression of damping-off disease caused by Pythium sylvaticum. Appl. Environ. Microbiol. 72:6452-6460.

18. Hyder, N., Coffey, M. D., and Stanghellini, M. E. 2009. Viability of oomycete propagules following ingestion and excretion by fungus gnats, shore flies, and snails. Plant Dis. 93:720-726.

19. Jarvis, W. R., Shipp, J. L., and Gardiner, R. B. 1993. Transmission of Pythium aphanidermatum to greenhouse cucumber by the fungus gnat Bradysia impatiens (Diptera: Sciaridae). Ann. Appl. Biol. 122: 23-29.

20. Johnson, L. F., Qian, P., and Ferriss, R. S. 1990. Soil matric potential effects on changes in wall morphology, germination, and lysis of oospores of Pythium ultimum. Phytopathology 80:1357-1361.

21. Kageyama, K., Uchino, H., and Hyakumachi, M. 1998. Characterization of the hyphal swelling group of Pythium: DNA polymorphisms and cultural and morphological characteristics. Plant Dis. 82:218-222.

22. Kalb, D. W., and Millar, R. L. 1986. Dispersal of Verticillium albo-atrum by the fungus gnat (Bradysia impatiens). Plant Dis. 70:752-753.

23. Kennedy, M. K. 1974. Survival and development of Bradysia impatiens (Diptera: Sciaridae) on fungal and non-fungal food sources. Ann. Entomol. Soc. Am. 67:745-749.

24. Latin, R. X., and Reed, G. L. 1985. Effect of root feeding by striped cucumber beetle larvae on the incidence and severity of Fusarium wilt of muskmelon. Phytopathology 75:209-211.

25. Leath, K. T., and Newton, R. C. 1969. Interaction of a fungus gnat, Bradysia sp. (Sciaridae) with Fusarium spp. on alfalfa and red clover. Phytopathology 59:257-258.

26. Lévesque, C. A., and De Cock, W. A. M. 2004. Molecular phylogeny and taxonomy of the genus Pythium. Mycol. Res. 108:1363-1383.

27. Martin, F. N. 2000. Phylogenetic relationships of some Pythium species inferred from sequence analysis of the mitochondrially encoded cytochrome oxidase I and II genes. Mycologia 92:711-727.

28. Matthews, V. D. 1931. Studies on the Genus Pythium. The University of North Carolina Press, Chapel Hill.

29. Mercier, L. 1911. Sur le role des insectes comme agents de propagation de l'ergot des graminées. C. R. Soc. Biol. (Paris) 70:300-302.

30. Mondal, S. N., Kageyama, K., and Hyakumachi, M. 1996. Decreased germinability and virulence of oospores of Pythium aphanidermatum in relation to loss of endogenous carbon during incubation on soil. Soil Biol. Biochem. 28:545-553

31. Ruben, D. M., Frank, Z. R., and Chet, I. 1980. Factors affecting behavior and developmental synchrony of germinating oospores of Pythium aphanidermatum. Phytopathology 70:54-59.

32. SAS Institute. 2002 JMP Statistics and Graphics Guide: Version 4. SAS Institute Inc., Cary, NC.

33. Stanghellini, M. E., and Hancock, J. G. 1971. The sporangium of Pythium ultimum as a survival structure in soil. Phytopathology 61:157-164.

34. Stanghellini, M. E., and Russell, J. D. 1973. Germination in vitro of Pythium aphanidermatum oospores. Phytopathology 63:133-137.

35. Steffan, W. A. 1966. A generic revision of the family Sciaridae (Diptera) of America north of Mexico. Univ. Calif. Publ. Entomol. 44:1-77.

36. Tahvonen, R. 1993. The disease suppressiveness of light coloured sphagnum peat and biocontrol of plant diseases with Streptomyces sp. Acta Hortic. 342:37-42.

37. Van der Plaats-Niterink, A. J. 1981. Monograph of the genus Pythium. Stud. Mycol. 21:1-239.

38. Wilkinson, J. D., and Daugherty, D. M. 1970. The biology and immature stages of Bradysia impatiens (Diptera: Sciaridae). Ann. Entomol. Soc. Am. 63:656-660. 